\title{
Shimomura Kôtarô (1863-1937) and the Circulation of Technical Knowledge between the United States, Japan, and Belgium
}

Shimomura Kôtarô (1863-1937) et la circulation des savoirs techniques entre les États-Unis, le Japon et la Belgique

下村孝太郎（1863-1937）與美、日、比利時之間技術知識的傳播

\section{Aleksandra Kobiljski}

\section{OpenEdition}

\section{Journals}

Electronic version

URL: http://journals.openedition.org/extremeorient/313

DOI: $10.4000 /$ extremeorient.313

ISSN: 2108-7105

Publisher

Presses universitaires de Vincennes

\section{Printed version}

Date of publication: 31 December 2013

Number of pages: 155-189

ISBN: 978-2-84292-404-1

ISSN: 0754-5010

Electronic reference

Aleksandra Kobiljski, « Shimomura Kôtarô (1863-1937) and the Circulation of Technical Knowledge between the United States, Japan, and Belgium », Extrême-Orient Extrême-Occident [Online], 36 | 2013, Online since 01 June 2017, connection on 30 April 2019. URL : http://journals.openedition.org/ extremeorient/313; DOI : 10.4000/extremeorient.313 


\title{
Shimomura Kôtarô (1863-1937) and the Circulation of Technical Knowledge between the United States, Japan, and Belgium ${ }^{1}$
}

\author{
Aleksandra Kobiljski
}

Sometime in 1873, in an innovative domain school in northern Kyûshû, one young student, Shimomura Kôtarô (1863-1937), placed a tree leaf in his desk drawer and started reading the Gospel of Matthew. ${ }^{2}$ His hope was that in so doing he would be able to induce the leaf's transformation into gold. Recounted in his autobiographical writings many years later, this episode is more than a negligible example of simple childhood reverie. In fact, it is a hallmark of Shimomura's career as a chemical engineer whose life's work seemed to his European colleagues equally impossible: turning highly bituminous Japanese coal (40\% volatile matter on average) into anthracite-grade coal (around 10\% volatile matter). ${ }^{3}$

The present article, which examines the itinerary and work of this chemist and engineer, is a product of the confluence of two lines of inquiry: an investigation into innovation in coking technology and its role in the emergence

1. This article would have been impossible without the generous help of the staff at the Dôshisha University Archive (Kyoto, Japan), especially Tomoko Fuse, who shared my passion for opening dusty boxes, odd-sized blueprints, and unwieldy rolls of correspondence. I am grateful to Muneharu Kitagaki, Asako Matsuki, Catherine Jami, Delphine Spicq, Antonella Romano, Annick Guénel, Nicolas Coupain, and two anonymous reviewers for helpful and stimulating comments on an earlier version of this article. The research was supported by a fellowship from Harvard University (USA), the ANR (France) grant ICCM ANR-09-SSOC-004, and the D. Kim Foundation for the History of Science and Technology in East Asia (USA). The Needham Research Institute has provided an intellectual home for the final corrections of the article.

2. All Japanese names in this article are listed in their customary order in which surname precedes the given name.

3. English-language studies on Shimomura Kôtarô are non-existent and those in Japanese are scarce. See Shimao 1975: 4-10, Shimao 1991: 197-210, and Shimao 2002: 102109. 
of modern steel industry in Japan on the one hand and an investigation into the impact of human mobility on the circulation of scientific and technological knowledge on the other. The first is inspired by the author's personal research in progress and based in large part on the private archives of a key figure in the early history of byproduct coking in Japan. The other is inspired by the author's participation in a collective research project focusing on the role of individual mobility in the circulation of scientific and technical knowledge in China. ${ }^{4}$ This article focuses on Shimomura's itinerary between Japan the United States and Europe as well as within Japan itself in pursuit of the scientific knowledge and technical expertise he would put to use in developing a particular coking protocol.

Shimomura's itinerary is that of an engineer whose atypical career path has resulted in his historiographical marginalization. This is, first, the result of his educational background. In his seminal work, Foundation of Science in Japan: Building a Research Tradition, James Bartholomew discusses the work and career of a number of Japanese scientists over a period of four decades. All of them were either graduates or students of the Imperial University of Tokyo. In a recent article on the struggle of engineers to improve their social status, Erich Pauer discusses a number of Japanese engineers in the first half of the twentieth century, all of whom were also Imperial University graduates. ${ }^{5}$ Shimomura, however, was educated at a small, American-staffed Protestant college in Kyoto, entirely outside of and partially at odds with the Imperial University's network. Second, he was one of only a handful of Japanese scientists who had a lasting connection with the Christian faith. Converting at the age of twelve, he grew to see his faith as a continuation of his scientific pursuit to understand the universe, not as opposed to it. ${ }^{6}$ Third, he was a chemist trained in the United States, and not, as was the norm at the time in Germany. Consequently, in building his professional and personal networks, he gravitated towards New England rather than Germany. Finally, his career included an uncommon switch from academia to the world of industry, as he went from being a chemistry teacher to a chemical engineer.

Although he worked on the margins of the scientific and industrial landscape of his time, Shimomura left his mark on both. Perhaps paradoxically, his contribution was both made possible and obscured by the singularity of his

4. ICCM (Itinéraires individuels et circulation des savoirs scientifiques et techniques en Chine moderne, $\mathrm{XVI}^{\mathrm{e}}-\mathrm{XX}^{\mathrm{e}}$ siècle) ANR-09-SSOC-004.

5. Pauer 2013.

6. For an introduction to Shimomura's ideas on faith and science, see Kobiljski 2014 (forthcoming). 
intellectual path within the context of the emerging scientific and industrial establishment. His education, outside the dominant networks, enabled him to effectively question received wisdom on what is done or possible. By questioning the limits of the possible or practical, he was able to produce locally the kind of fuel without which the nascent Japanese steel industry would have come to a standstill in the early 1900s. This success was further facilitated by the fact that he worked in a relatively small private company, where his technical decisions were not under the scrutiny of a host of bureaucrats, as was common in state-run enterprises. At the same time, his positioning on the margins of both state academic institutions and major military-industrial venues throughout his career made his contribution to putting in place Yawata Steel Works'coking plant possible. ${ }^{7} \mathrm{He}$ was neither a Tokyo alumnus nor had he studied in Germany; he was not an employee but merely a consultant at Yawata. As such, he has been almost completely excluded from most accounts of Yawata's early years and subsequent accounts of coking innovation at the company in favor of a later generation of Yawata coke experts, such as Kuroda Taizô (1883-1961), whom he helped train.

Finally, as a study of a individual itinerary, this analysis - as well the project within which it developed - is anchored to a greater or lesser degree in biographical study. In the eyes of many historians of science and technology, biography - understood to mean history of great men and their inventions has long been a marginalized genre in academic if not trade publishing. The recent revival of interest in the utility of biography (and biographical data) for historical inquiry has been coupled with a rethinking of the biographical method, which developed in parallel in history and sociology. In its initial incarnation, it came largely from scholars working on European and North American societies. Nevertheless, some of the most innovative uses of biographical data have emerged in other modern historiographies-for example in the history of the late Ottoman Empire (1299-1922) or of Qing China (1644-1911). ${ }^{8}$ These works rely on culling information from relatively large data pools, such as local gazetteers in China (difang zhi) or career records of Ottoman bureaucrats found in the Register of the conditions [of state employees] (Sicill-i Ahval Defterleri), which contains over 50,000 personnel records. As such, they rely on new technology that allows the manipulation of data sets following a clear definition of parameters used in collection and analysis. Methodologically, such biographical studies make a strong case for a

7. See the extended discussion the Yawata Steel Works below.

8. See Feng and Shao 1994, Gyatso 1998, Bretelle-Establet 2009, Bouquet 2007, and Travers 2009. 
reasoned use of hitherto neglected sources of biographical data. Analytically, they offer what the French sociologist Jean-Claude Passeron calls "a degree of aggregation of synchronic properties," ${ }^{9}$ whether this be a collective portrait of social or professional groups, such as Chinese medical experts from the far south, demoted Tibetan officials, or promoted Ottoman bureaucrats.

This article is inspired by these works and benefits from their methodological reflections, although its analytical goal is slightly different. Rather than use biographical data to aim at a collective portrait, I use a single man's biographical sketch as a springboard into two questions of broad import for the study of the history of technology in Meiji Japan (1868-1912). First, Shimomura's individual itinerary and professional career are difficult to fit into currently existing typologies of the nascent and consequently fluid category of engineer in Meiji Japan. Thus the present article hopefully makes a contribution towards nuance in our understanding of where Meiji engineers came from in terms of educational background and professional paths. ${ }^{10}$ Second, it contributes to the literature on the role of small and medium companies in Japan's modernization drive.

Because of its exceptional character, Shimomura's career needs to be analyzed while keeping in mind the question of the relevance of an individual, non-representative case for historical inquiry. These issues have been raised in the context of two decades of debates about the scale of historical analysis, notably within the context of micro-history. As one among several critical trends of the 1980s and 1990s, micro-history represents a reaction to macrohistorical approaches that, in many different forms, dominated historiography. At its core lies an effort to make visible individual historical actors and their experiences of large-scale social and historical processes. Methodologically, it decoupled the notion of scale and importance, and, in a relatively short span of time, it helped revise axioms on the construction of historical subject. For example, it is not widely accepted that the process of industrialization was not simply a capital-labor-technology macro dynamic but needs to be understood in terms of the experiences of individuals and the logic that guided their choices and paths. ${ }^{11}$ In outlining Shimomura's career, this article does not aim to "give the microphone to an ant," as critics may suggest, but rather use an

9. Passeron 1990: 6.

10. For a classic examination of the industrialization of Japan from the perspective of the history of technology, with special emphasis on technological innovation and its actors, see Nakaoka 2006. For a recent study of technical education and professionalization, see Sawai 2012.

11. Revel 1996: 7-36. 
ant-Shimomura Kôtarô-to ask questions and generate hypotheses about a certain segment of the anthill's history-the industrialization of Japan in the Meiji period (1868-1912) and its actors.

\section{The making of a chemist (1872-1895): Kumamoto to Kyoto}

Shimomura was born in 1863, the first son and the heir of a low-ranking samurai family in Kumamoto, on the island of Kyûshû. Kumamoto, the capital of the Higo domain, the fifth largest domain in Tokugawa Japan (1600-1868), was officially taxed at 540,000 bales of rice or koku but with an actual annual income of some 720,000 koku (a koku was an official measure of volume, and in Edo, the capital, 1 koku was approximately 278.3 liters). Although officially an outside or tozama domain and thus barred from the Tokugawa government's inner administrative circle, Higo had established close ties to the Shogunate. By the later part of the Tokugawa period, it was one of not only the largest but also the most influential outside domains, known for its staunch conservatism. Although, at least since the $1850 \mathrm{~s}$, both the signs of weakness in the Shogunate and the need to end Japan's seclusion were evident, the Higo leadership was unable to respond to the growing sense of crisis in any way other than to uphold the existing order. Thus, Higo's conservatism effectively prevented it from participating in the reform movement driving the Restoration in the 1850s and 1860s. It was Higo's neighboring domains - the Satsuma to the south, Hizen to the north, and the nearby Chôshû and Tosa-that took the intellectual and military initiative in the movement that would become known as the 1868 Meiji Restoration. By 1870, having risked and invested in the uncertain project of regime change, those domains were reaping the dividends of the transition while Higo was being bypassed.

If Higo was not to be left behind by the "new" Japan, the domain's leadership had to find a way to change its official ideological orientation, which rested on a particular interpretation of Neo-Confucianism that had buttressed feudal Japan. This meant a struggle against the domain's official academy - the Jishûkan, the bastion of this orthodoxy-and an entrenched group of political actors gathered under the banner of the so-called School Party (Gakkotô), which had run Kumamoto politics before and was still a force in the aftermath of the 1868 Restoration.

The job of reforming the intellectual heart of the domain fell to long-time opposition figures, literati loosely gathered around the Practical Learning Party (Jitsugakutô), which centered on Yokoi Shônan (1809-1869) and his 
students. ${ }^{12}$ During the 1840 s and 1850 s, Yokoi taught in his private academy in Kumamoto and attracted students from two social groups: lower-ranking samurai youth and the sons of wealthy peasants. By the mid-nineteenth century, the latter group had grown rich and saw economic and social opportunities in the changes taking place in the late Tokugawa period. Aspiring to buy their way into the status of low-ranking samurai, they shared with them a keen interest in and concern for practicality. While for the low-ranking samurai this was a matter of survival amid rising inflation and diminishing stipends, for wealthy peasants it was a question of maximizing their economic well-being.

In 1863 (the year of Shimomura's birth), Yokoi was placed under house arrest outside Kumamoto and stripped of his stipend. The immediate cause was the circulation of his seminal tract on three issues in state policy, the Kokuzen sanron, which would later serve as one of the foundation texts of early Meiji statecraft. ${ }^{13}$ Yokoi was released five years later, in the aftermath of the Restoration, and left Kumamoto for Kyoto, where he advised the emperor on the reform that he had spent decades advocating. Only months after his release, he was assassinated in Kyoto by a group of lordless samurai (rônin) who were opponents of the Restoration.

Although he was an important architect of the movement that brought about the Restoration, Yokoi did not live to see the implementation of reforms he helped engineer. But his legacy was felt in some of the most important documents of the Meiji Restoration; one of his students wrote his ideas into the Charter Oath, a document that outlined the Restoration's aims promulgated on April 7, 1868. To Shimomura, who was five years old at the time, Yokoi's posthumous reputation as a proto-architect of the Restoration may not have meant much had it not had another, very local, incarnation. Yokoi's teaching became the foundation of a plan drawn two years after his assassination to establish a school that was to become Shimomura's first training ground, the Kumamoto School of Western Learning. ${ }^{14}$ In 1870, as the tide of change was rising, two of Yokoi's students - Tokutomi Ikkei (1822-1914) and Takezaki Sadô (1812-1877) - and a number of their supporters seized the opportunity to

12. Discussion of Yokoi's ideas in English can be found in Harootunian 1970. For an English translation of Shonan's Kokuze sanron, his seminal 1860 tract, see Miyauchi 1968.

13. Strictly speaking, the Kokuze sanron was written down by one of Yokoi's students during his stay in Fukui domain where he was invited by its lord Matsudaira Shungaku (1828-1890) to teach. Therefore, it consists of a text based on lecture notes followed by questions and answers.

14. For Yokoi's legacy in the Kumamoto School of Western Learning, I used a classic biography of Yokoi in Japanese; see Yamazaki 1938. See also Notehelfer 1985. 
depose the conservative officials in power. Their offensive began with a reform initiative: a call on Higo's domain lord to return from Tokyo and undertake sweeping administrative and fiscal reforms. Echoing Yokoi's considerable concern with educational reform and his insistence on the opening of Japan to the outside world and education, they made establishing of a new kind of school an important part of the reform agenda. The return of Lord Hosokawa to Kumamoto in May, 1870, marked the implementation of this plan and led to what was to be called the Higo Restoration.

The newly founded Kumamoto School for Western Learning, the Kumamoto yôgakko, had the task of combining Japan's Confucian ethics with Western science and technology, most importantly those elements that could help prop up Japan's military apparatus and devise new defense strategies. For that purpose, the founders developed a school and a curriculum divided between the study of Confucian classics on the one hand and what they called Western learning (yôgaku), a mix of English language, geography, history, literature, and a science curriculum that included chemistry, physics, astronomy, and mathematics. To take charge of the "Western" part of this curriculum, in 1871 the Kumamoto domain arranged to hire a West Point graduate and US Civil War veteran, Captain Leroy Lansing Janes (1837-1909). ${ }^{15}$ His teaching was an indispensable ingredient of a policy intended to immunize Japan from weakness. By hiring an American military man, the Kumamoto proponents of practical learning sought to follow a well-known belief of the day: that there could be no better combination than that of Japanese spirituality with Western technology. Yokoi was an early proponent of the policy, which by 1870 had become one of the early Meiji period's slogans: "Japanese spirit and Western technology," or Wakon yôsai. ${ }^{16}$ However, Janes'task was neither pedagogically simple nor socially without its challenges. It meant teaching students who spoke no English while living with his wife well outside the treaty ports, a life

15. For an English-language account of Janes'stay in Japan, see Janes 1970. For a synthetic historical account of Janes'teaching years in Japan, see Notehelfer 1985: 130-178. For a Japanese-language account of the experience of his students in his classroom see, for example, Ebina, 1935.

16. This was a Meiji version of a late-Tokugawa period slogan Tôyô no dôtoku, seiyô no gakugei or "Eastern ethics and Western Science" popularized by Sakuma Shôzan (1811-1864). Although reformulated and widely used in the early Meiji period, this slogan was used well into the twentieth century. See, among others, Mizuno, 2008: 57. 
isolated in the Japanese interior. He spoke no Japanese, and it is not clear to what point any of his hosts had a functional command of English. ${ }^{17}$

These were turbulent times, since the school had opened its doors only four years after the emperor was brought or "restored" to power and Japan embarked on what seemed a path of unprecedented changes. In 1872, when the school was in its second year and Shimomura enrolled, the central government announced the abolition of hereditary stipends for samurai families. For Shimomura, the opportunity to attend the school was an exciting encounter with the basics of the science curriculum as it was taught to children of his age in the United States. He was nine years old, four years younger than the average student in the class, and for him, as for many of his peers, Janes was the first foreigner he had ever seen. At the same time, the scholarship to attend the Kumamoto School for Western Learning gave him a chance to receive an education that could help a youngster designated as his family's heir weather a profound social crisis.

In pursuit of a mixture of Western learning and Japanese spirit, the students'days at the Kumamoto's yôgakko were divided in two parts: instruction in English language, physics, astronomy, chemistry, mathematics, geography, and military drill on the one hand, and a Confucian Classics curriculum of reading, reciting, and composition in Classical Chinese on the other. However, the mission of grafting modern science onto a basis of Confucian ethics did not proceed as smoothly as planned. Early in the school year, Captain Janes and Takezaki sensei, the school's famous Confucian scholar, found themselves in a position of rivalry. ${ }^{18}$ It did not help that they knew little about each other and were prejudiced toward each other's world view. Takezaki and other Japanese teachers referred to Christianity in derogatory terms. ${ }^{19}$ Janes

17. Details on the tasks of the school and desired qualifications of the foreign teachers to be hired at the Kumamoto School of Western Learning are outlined in Higo han kokuji shiryô 1932: 691-3.

18. Sensei is a noun designating a teacher, a professor, or in certain cases religious dignitaries and is obligatorily used to address them or refer to them.

19. This was not surprising in view of the official governmental ban on Christianity in Japan that was still in effect when Janes arrived in 1871 and in light of Kumamoto's staunch anti-Christian atmosphere, which persisted even after the ban was lifted in 1872. Although liberal on the question of opening Japan to the world, even proponents of practical learning were anti-Christian. In his autobiography, Shimomura recalls the school principal using the term kirisutan bateren, more commonly given as kirishitan bateren, a derogatory designation for Christianity in the Tokugawa period. Some of the students used the same designation. The word bateren comes from the Portuguese for a Catholic priest, padre. See Shimomura 1931: 6, 10. 
went into the dormitory rooms of his students and snatched their "Chinese books"- probably not realizing that much of what he was confiscating were not Confucian Classics but adventure novels. ${ }^{20}$ Regardless of their level of (in) comprehension, Janes spoke only English to his students and seems not to have learned more than a few words of Japanese. He pursued the English section of the curriculum as if the Confucian section did not exist; the same was true of his Japanese counterparts. At the heart of the matter lay two different visions of the place of science and technology in a modernizing society. Jitsugaku (practical learning) scholars argued it was possible (and necessary) to cherrypick elements of an intellectual tradition, in this case a science curriculum and military tactics, and mix them with a curriculum based on Neo-Confucian precepts. On the other hand, Captain Janes-like many of his Protestant missionary contemporaries-believed that Christianity was at the core of Western civilization and technological progress. Although, for the first four years of teaching, Janes did not spell out his views, in his mind it followed that importing Western technology was futile if not accompanied by its ethical source: Christian morality and faith. ${ }^{21}$

For many Kumamoto students of the first generation, the school experience was a rather destabilizing one. The pedagogy behind the experiment seemed to imply that the mixture of Confucian ethics and Western science was to materialize not in discussions between the teachers but in the minds of the students. In other words, the main work of harmonizing two intellectual perspectives and of actually grafting one onto the other was left to the Kumamoto domain's brightest teenagers. This was no small responsibility, as the combination was perceived to be the key to their country's self-strengthening and modernization project. $^{22}$

When Shimomura's American teacher first arrived in Kumamoto, he brought with him a vision of a Christian as a radical reformer in the service of his community. For many boys in his class, becoming leading reformers of their society, being a moral example, and using science and technology to improve the lives of those around was exactly what they aspired to. What Janes

20. Ibid:: 8-9.

21. For an analysis of the different shades of Janes'Christianity and how it changed during his Kumamoto years, see Notehelfer 1985: 179-209.

22. Even the Kumamoto students'later embrace of Christianity did not entail a complete rejection of Confucianism. Rather, it marked the beginning of another stage of grafting a version of Protestant values onto a late Edo - period inflection of Neo-Confucian ethics that was characteristic of early Meiji Christians. For an analysis of one of Janes'student's life-long blending of Confucianism and Christianity, see Ballhatchet 1988. 
believed and was teaching his students without saying so explicitly was that this kind of service to the community was in itself a form of prayer. Without confronting them with the Bible but by teaching about science, technology, and nature, Janes was preaching God's "other book." In the words of one of his students, this was a kind of preaching that did not require words. ${ }^{23}$ As time went by and, in part, due to his social isolation in Kumamoto, Janes turned to faith and experienced a personal renewal. ${ }^{24}$ With his new-born faith came a conviction that learning astronomy, botany, and English could not strengthen Japan if his boys did not understand Christianity, the ostensible core of the civilized ways his students were trying to penetrate. Very few Japanese at the time and not many foreigners other than the missionaries subscribed to the idea that Japan had to Christianize to be counted among the civilized nations. Lafcadio Hearn, a long-time American resident of Japan, illustrated the sentiment when he wrote that "Japan has nothing to gain by Christianity." ${ }^{25}$ Yet Janes came to Kumamoto in early 1871 believing that there was a direct link between Western progress and its Christian ethos, and he came to be a living example of it in and out of the classroom. ${ }^{26}$

His educational philosophy aside, upon his arrival Janes had to concentrate most of his energies on overcoming the language barrier which is why the first year of study was devoted to intensive learning of English, military drills, and the basics of Western-style arithmetic or yôsan. ${ }^{27}$ As soon as they could communicate in English, some of the older students challenged Janes'vision by reciting arguments for Confucian superiority over Christianity. ${ }^{28}$ Although by this time the second half of the popular late Tokugawa period (1600-1868) slogan "revere the Emperor and repel the barbarians" (sonno jôi) had been quietly dropped from political discourse, many of his students grew up with

23. As cited in Notehelfer 1985: 181, from the now apparently lost Fukunaga 1893: 82.

24. Some mission historians have subsequently suggested that Janes was sent by a missionary organization; see Andersen 1999: 327. The attempts to claim him as a missionary are grossly inaccurate. After being dismissed from his teaching position in Kumamoto, when Janes wanted to become a missionary, the American Board of Commissioners for Foreign Missions (ABCFM) rejected the idea, despite the unanimous support of their missionaries stationed in Japan. See Notehelfer 1985: 210217.

25. Hearn to Chamberlain, January 19, 1893, in Hearn 1922: vol. 15, 359.

26. Notehlefer 1985: 192.

27. On the Japanese mathematics tradition referred to as wasan, see Horiuchi 2010: esp. xix-xxvii, on the scope of the term.

28. Kozaki 1933: 35-36. 
the image of Westerners as barbarians. ${ }^{29}$ However, with time, the intensity of the contact between the students and their American teacher, coupled with Janes'enthusiasm for his students and passion for teaching worked to chip away the layers of his students'cultural discomfort with and intellectual prejudice against foreigners. The more they got to know Janes, the more he looked like an American version of a samurai. ${ }^{30}$ This made them more attentive to his message. And thus, students and teacher changed each other's lives.

\section{The boy who wanted to go to the moon}

In the winter 1875, Janes started organizing weekly Bible study meetings at his home for interested students. Usually these sessions started with prayer by him, continued with Bible reading and discussion, and closed with hymn singing. The word soon spread around the school that Janes was talking about magical things, possibly a misinterpretation of Janes'explanations of Jesus'miracles such as walking on water, curing the sick, and feeding the hungry. While Janes meant this as proof of Jesus'credentials as the Son of God, at least some of his students understood it to be a story of a powerful Western sorcerer with tricks up his sleeve. Shimomura was one of these. Before entering Kumamoto School for Western Learning, Shimomura spent hours reading Takizawa Bakin's magic-infused The Eight Dog Chronicle (Hakkenden), a serialized novel from the late Tokugawa period (1600-1868) which remained popular well into the nineteenth century. Reading it stimulated the child Shimomura's interest in mastering the magic that made the adventures and transformations described in the novel possible. A little later, during his Kumamoto school days, a fellow student suggested reading and gave him a copy of "a Christian book" (kirishitan bateren hon) that could help him learn about Western alchemy and magic. ${ }^{31}$ Both boys were interested in magic, and one of Shimomura's projects was to try to turn an ordinary tree leaf into a golden one by stashing it in a desk drawer and reading the Bible. ${ }^{32}$ Although

29. Following common practice, I translate the late Tokugawa period slogan sonno jôi as "Revere the emperor and repel the barbarians." Jô $i$ is ocasionally translated as "expel foreigners" because the more neutral "foreigner" better suits contemporary sensibilities of political correctness. I use the term "barbarian" because it conveys the sensibility of the period.

30. Notehelfer 1985: 104, 149.

31. Its virtually impossible to identify precisely which book it was.

32. Shimomura 1931: 6 . 
his attempts failed, young Shimomura continued searching. A reading of the Gospel of Matthew - where the miracle of the seven loaves and fishes is described-confirmed his understanding of Jesus as a master of magic tricks. ${ }^{33}$

After his attempt to turn a leaf into gold, Shimomura's interest in astronomy brought about a new fascination with going to the Moon, which led him to his first prayer meeting. Following the contemporary logic of belief in the superiority of Western science, it was a small step for eleven-year-old Shimomura to assume the superiority of Western magic and sorcery over its Japanese counterpart. From the students'viewpoint, Janes spoke of magic (the Second Coming of Christ, Jesus'return to the Earth) and supernatural acts (Jesus'miracles). During the meetings, Janes, like Jesus before performing the miracle of the loaves and fishes, often looked up to the sky when offering prayers and giving thanks. Thus, Shimomura had reason to believe "that the study of Christianity enables one to learn the way of going to the Moon" and that Janes could help with that. ${ }^{34}$ Teach about Christianity he did, although not in the manner that Shimomura expected.

In February 1876, during his fifth year at Kumamoto, Janes led a group of 40 (out of an estimated 200) students to a nearby hill where they read a Covenant, a document defining their conversion to Protestant Christianity. ${ }^{35}$ While school authorities expected them to add Western science and technology to their Confucian education, the boys had become convinced that that "there is a chain connection between Christianity and Western learning." ${ }^{36}$ Embracing Christianity seemed a way of fulfilling their Confucian duty to their teacher, the school's mission, and their country's future. But their parents and the school administration disagreed. Janes was dismissed, while his students faced various degrees of family wrath. Some spent weeks in confinement, some were even deprived of water and food for days. Shimomura was an exception; during the interrogation that followed he could calmly say that he obtained his father's permission to become a Christian, leaving the school's principal, certain professor Morita, at a loss for words. ${ }^{37}$

A few months later, before leaving Japan, Janes secured the admission of all forty of his protégés to Dôshisha, a newly founded Protestant college in

33. Shimomura refers to a woodblock-print edition of the Gospel of Matthew, which was likely Hepburn's translation, printed in 1873; see Cohen 2013: 30-41.

34. Kiristosha retsuden: shinkô sanjûnen 1921: 56.

35. My estimate is based on a register of students transcribed by an unknown author and found in the Kumamoto Prefectural Library, Archive section, call no. 0112610.

36. Shimomura 1931: 7.

37. Shimomura 1931: 8 . 
Kyoto, which enabled them to escape further persecution in Kumamoto. There, Shimomura continued his education under two tutors: an American, Jerome Davis, graduate of Beloit College (in the US state of Wisconsin) and Niijima Jô (1843-1890), a Christian convert and a graduate of Amherst College and Andover Theological Seminary (both in Massachusetts), at whose initiative Dôshisha was established in 1875. Shimomura spent most of his time studying scientific subjects sandwiched between morning and evening prayer, with weekly Bible study on the Sabbath. After the loss of his stipend, Shimomura's father had started an agricultural venture, but his death in 1876 left Shimomura responsible for supporting the family. After graduation in 1879, Shimomura briefly returned to Kumamoto before being called back to teach at Dôshisha; he then settled in Kyoto with his mother and sisters.

During his first round as a teacher at Dôshisha, from 1882 to 1885, like his other colleagues, Shimomura taught a wide variety of subjects, including natural philosophy, physics, astronomy and geology, reading and spelling (English), rhetoric (Japanese), history of civilization, history of the United States, arithmetic, and algebra. Yet he gradually started specializing in teaching mostly physics, chemistry, and mathematics, and by 1885 the college prospectus lists him as a designated teacher of these three subjects. ${ }^{38}$

His students described him as a dedicated teacher, "a profound thinker" and not dogmatic. ${ }^{39}$ "Sensei was the kind of man," one student remembered, "who would clearly say 'I don't know'when he didn't and 'I don't understand'when he didn't." ${ }^{40}$ To those students who asked, he would give additional help and lessons, becoming one of busiest teachers in the college. ${ }^{41}$ Perhaps the most remarkable aspect of Shimomura's first teaching period was the breadth of mind with which he mentored his students. As revealed in a diary of one of his students, to those students who sought advice on how to prepare for Christian work, he recommended not the study of the Bible, but that of politics and economics. "Looking at the current situation of the country," Shimomura told them "for the next forty or fifty years, I urge you to pay attention to politics. If you don't know everything about it, you will get laughed at and surely sully

38. Dôshisha circular 1885 . Faculty records for $1882 / 3$ and $1883 / 4$ show that his teaching load was very varied. See Dôshisha Faculty Records 1879-1895 (2004): 36-55. The mention of Shimomura teaching Japanese rhetoric is from Abe Isoo's diary entry for January 10, 1884. See Abe 2009: 74.

39. Sôritsuki no Dôshisha: sotsugyôseitachi no kaisorokoku 1986: 26.

40. Ibid.

41. Abe diary entry for September 28, 1883, reads: “At 4 p.m., went to Mr. Shimomura's house to take the exam in the History of Western Civilization.” See Abe 2009: 66. 
the reputation of Christianity." ${ }^{42}$ When abandoning traditions was the slogan of the day and in the middle of the Meiji government's campaign against the Buddhist establishment, Shimomura urged his students with evangelistic ambitions to study the Confucian classics and the basic tenets of Buddhism. ${ }^{43}$ Finally, he urged them to worry not only about ideas but also about the practical challenges of building a country while keeping in mind that Japan "is different from other countries in terms of how things are done." ${ }^{44}$

\section{From Japan to the United States and back}

Around the time he became Dôshisha's principal teacher of physics and chemistry, Shimomura started thinking intensively about going abroad for further study. Consistent with the advice he was giving his students about learning about the world around them in order to be of good service to Christianity, he too wished to become a better scientist and thus a better advocate for Christianity in Japan. Believing that "whether politically or morally, Christianity alone can save Japan," he proceeded to define the "the lack of Christian scientists" 45 as the greatest need of the moment and the biggest obstacle in this struggle. ${ }^{46}$ By 1884 , Shimomura was eager to go abroad for further scientific study. "The idea of going to the West has occupied my mind for the last five years," he wrote (in English) to Dôshisha's president and his mentor Niijima, "and now my heart burns. I pray for the opening of the way. I feel my future usefulness depends upon it." ${ }^{47}$

The first step on his way to the United States was overcoming the reluctance of the American missionaries at Dôshisha, whose approval and connections were essential for the realization of his plan. In the late summer of 1885, he sailed for the Worcester Polytechnic Institute (WPI) in Worcester, Massachusetts. Once there, Shimomura found that he was behind in his "knowledge of technical and scientific terms" and decided he was "not fond of mathematics." However, in the words of WPI's director about his first Japanese

42. Abe diary entry for August 5, 1884; see Abe 2009: 68-69.

43. For a self-definition of their aspiration to be men of education, see Shimomura Kôtarô, The Aim of My Life.

44. Abe diary entry for August 5, 1884; see Abe 2009: 68-69.

45. Shimomura, Kôtarô to Jô Niijima, Kyoto, 9 September, 1884, in Niijima Jô ate eibun shomotsu 2007: 265.

46. Ibid., 266.

47. Ibid., 267. 
student, Shimomura "applied himself so diligently that he soon took high rank in one of the best classes the [Worcester] 'Tech'ever had," and in the year of his graduation he was voted the smartest person of the class of $1888 .{ }^{48}$

In 1888, Shimomura obtained his Bachelor of Science (BS) degree with a thesis on theories of the formation of chemical elements, graduating second in his class. Instead of returning to Japan and reassuming his teaching position, as his family and colleagues expected, Shimomura decided to enroll in a $\mathrm{PhD}$ program in chemistry at Johns Hopkins University so as to "broaden [his] knowledge of Chemistry." ${ }^{49}$ He went to study with Ira Remsen (1846-1927), the founder of the American Chemical Journal, one of the original faculty members at the Johns Hopkins University and the head of the laboratory that discovered saccharin..$^{50}$ A year later, in 1889 , he obtained a $\mathrm{PhD}$ degree in chemistry, in a short period not uncommon at the time. He again delayed his return for the purpose of fundraising for Dôshisha's new School of Science. "I believe," he wrote, "one who does to the school the greatest good [...] is he who helps to put [it] in a firm financial condition and not he who comes back glittering with his degrees [...] to sit down in an easy professor's chair." ${ }^{51}$ Thanks to the introductions of friends, missionaries, and acquaintances, he had the good fortune of meeting Jonathan Newton Harris, a New London, Connecticut, entrepreneur. ${ }^{52}$ Shimomura's science background combined with his faith seems to have deeply impressed Harris, who consequently decided to give him a $\$ 100,000$ endowment with additional smaller sums for special purposes (including $\$ 10,000$ for erecting a specialized building with an observatory, $\$ 8,000$ for laboratory equipment, books, and Shimomura's travel expenses). ${ }^{53}$ The interest from the endowment was intended to fund a new department for scientific work at Dôshisha, and the Harris School of Science opened in September 1890, the first of its kind at a private college in Japan.

To the great pleasure of both its principal benefactor and Shimomura himself, the Harris School of Science was a temple of science on a Protestant college campus, a living argument for the unity of religion and science. ${ }^{54}$ What

48. Homer T. Fuller, "Kotaro M. Shimomura," The Journal of the Worcester Polytechnic Institute 7 (1903-1904): 312; The Log, 64 (Worcester Polytechnic Institute Archive).

49. The Ferdinand Hamburger Archives of The Johns Hopkins University, Baltimore, Maryland; Record Group 13.010, subgroup 1, series 2 [Kotaro Shimomura].

50. Warner 2008.

51. Shimomura to Niijima. April 15, 1888. See Nijiima Jô eibun shomotsu 2007: 605.

52. Ibid:: 646 .

53. Dôshisha hyakunenshi vol.1. 1979: 373; Shimomura to Niijima, May 20, 1889, Nijiima Jô eibun shomotsu 2007: 695; August 25, 1889, ibid.: 716.

54. Dôshisha hyakunenshi vol. 1. 1979: 373-375. 
made any school of science worth its name and what stood at its heart was a well-equipped laboratory. "I must say frankly," Shimomura wrote during the negotiations for his return, "I cannot teach chemistry if you do not give me a chemical laboratory to work in; for I hold any matter of teaching chemistry but the laboratory \& study method has no educational value whatever." ${ }^{55} \mathrm{He}$ secured a separate grant from Harris for the purpose of purchasing best available German laboratory equipment. ${ }^{56}$ But Shimomura's laboratory teaching dream did not last. The opening of the new department coincided with the death of Dôshisha's principal founder and launched the institution into a crisis that would engulf Shimomura's career. After five years at the head of Dôshisha's School of Science, Shimomura resigned over a conflict with the administrators (who were also his childhood friends and fellow Kumamoto bando converts) over channeling of the Harris trust fund income towards the operating cost of the college preparatory department. Feeling that such a use was a breach of the donor's intent, Shimomura resigned in 1895 , leaving the world of academia, and was obliged to go into that of industry and applied research.

\section{The making of an engineer (1895-1914): Osaka to Brussels}

Personal and family reasons limited Shimomura's professional mobility, focusing his job search on the city of Osaka, a commercial hub and an emerging industrial city. ${ }^{57}$ Upon leaving Dôshisha, Shimomura became interested in the new technology of coking and was able to attract the attention of the Osakabased entrepreneur and banker Toyama Shûzô (1862-1916). ${ }^{58}$ With the support of Matsukata Masayoshi (1835-1924), Japan's longtime finance minister, Toyama undertook the opening of a chemical plant in Osaka, hired Shimomura, and sent him abroad for training. ${ }^{59}$ Records of Toyama's initial business plan are unclear, but judging by where he chose to send Shimomura, it seems that he planned to set up a byproduct coking plant so as to sell coke (perhaps to the Osaka Arsenal) while commercializing the byproducts, such as coal gas, coal tar, benzene, and/or ammonia.

55. Shimomura to Niijima, May 20, 1889. See Nijiima Jô eibun shomotsu 2007: 694; August 15, 1889, ibid:: 716; emphasis in the original.

56. Shimomura to Niijima, August 15, 1889; and see Shimomura to Niijima, May 20, 1889. And see Nijiima Jô eibun shomotsu 2007: 694.

57. For English sources on the rise of industrial Osaka, see Sawai 1999 and Mosk 2001.

58. The encounter is briefly mentioned in Shimomura 1925: 3

59. Shimao 1991: 199. 
When Shimomura went to Solvay \& Cie in Charleroi, Belgium, for training in 1897, he found himself at one of the leading chemical companies in Europe.$^{60}$ This trip was not simply a study trip or an inspection tour, but rather a transformative experience for a chemistry professor tasked with reinventing himself as a chemical engineer and coking specialist.

Coke is a solid fuel obtained by a process of coking, essentially the heating of coal in the absence of air so as to drive off the impurities commonly found in coal. There are many complex differences in techniques, but there are basically two ways of coking coal: 1) one that makes no provision for the recuperation of impurities that are driven off in the process, and 2) one that enables recuperation, processes the impurities, and commercializes the byproducts. ${ }^{61}$ Shimomura went to Belgium to train in a company that was one of the pioneers of byproduct coking and which, several years before his arrival, became confident enough to start expanding its coking operation internationally. ${ }^{62}$

Solvay \& Cie was established in 1863 by the chemical engineer Ernest Solvay (1838-1922), who had earned fame and fortune by patenting a process for manufacturing soda ash, an indispensable component in glass production, water treatment, and soap making. Cheaper and less polluting than the more common Leblanc method for producing soda ash, the Solvay method spread rapidly. In 1874, Solvay opened a larger plant in Nancy, France. Up until the middle of the 1880s, the Solvay soda ash plants obtained their ammonia from local gas plants, an arrangement that occasionally put a stress on supply due to transportation difficulties. ${ }^{63}$ This fact, along with ever-increasing production and concomitant profits made Solvay both interested in and able to invest in the research and development of byproduct coking technology.

Interestingly, the principal drive in developing what would become one of the most advanced coking technologies of its generation was not a need for coke itself but rather a demand for one of the byproducts of coke's productionammonia. Solvay's idea was to secure his own ammonia supply and offset the supply costs in part by the sale of coke to the metallurgical industry. In 1876, he gave Louis Semet (1844-1920) the responsibility for devising a technology

60. For the place of Solvay \& Cie in the context of the Belgian chemical industry and for a sketch of its early history, see Bertrams 2013; 65-97. For the overall importance of Belgium in the global chemical industry, see Haber 1971.

61. For a detailed technical description of both processes in contemporaneous coking manuals, see Fulton 1895: 92-229.

62. For detailed description of the technique as it was practiced at the time, see Fulton 1895, and for a slightly later period, see Dixon 1939.

63. Bertrams 2013: 59. 
mostly valued for its secondary production. Semet, who was Solvay's cousin and brother-in-law, had considerable experience in gas production. He was born into the family that owned the Saint-Josse gas plant near Brussels where he had begun his career. ${ }^{64}$ The prospects of developing an economically viable coke oven that would allow recovery of byproducts at a steady rate and at a reasonable cost seemed bleak in the late 1870s. A number of such experiments had taken place across Europe in the late 1860s, but they consistently failed to produced metallurgical grade coke and/or were commercially unviable because of high recovery costs. ${ }^{65}$ Likely starting with an improved Carves oven as the basis, by early 1882 the first battery consisting of six ovens that would become the Semet-Solvay type was built in Mons (40 kilometers west of the original Solvay soda plant at Charleroi) ${ }^{66} \mathrm{~A}$ second battery of twenty-five ovens was built in 1886 at the coal mine at Havré, just outside Mons, setting in place Solvay's business model for its coking plants. Typically, Solvay built batteries of ovens at its own cost at the customers'facilities. This arrangement benefited clients unwilling or unable to invest large sums of money in building and operating a coking plant. While the client received the coke that was produced, Solvay recuperated its investment by retaining the rights to all the byproducts. In 1892, the first battery of this type of ovens was built overseas, in Syracuse, New York, before expanding to Pennsylvania, Alabama, Kentucky, Ohio, Michigan, West Virginia, Massachusetts, and locations in Canada.

At present, few records are available on Shimomura's stay in Belgium, but it is certain that once he arrived in Brussels in April 1896, Shimomura went through intensive training. In addition to mastering the chemistry and physics of coking, he had to learn about how practically to go about setting up and operating the coking and recovering the valuable byproducts. His training was organized and supervised by William Kirkpatrick, a Solvay company engineer who was soon to become one of the two men responsible for the Solvay byproduct coking operation. ${ }^{67}$ Finally, while based in Brussels,

64. Ibid.

65. Burn 1961: 204.

66. Designed by François Carves and patented in Britain in 1879 and in the US in 1883 , the oven was designed as to collect some coal tar and ammonia emitted in the process of distillation. See: Specification forming part of Letters Patent no. 287,905, dated November 6, 1883, United States Patent Office. Accessible at www.google.com/ patents/US287905.

67. Personnel files, Archives of the Solvay Corporate Secretariat, Brussels. 
Shimomura traveled to England for the purpose of visiting the machine and mining equipment suppliers in Sheffield. ${ }^{68}$

Shimomura went to Belgium before the Osaka Chemical Works was even officially registered as a company. Upon his return, he was designated as the Director, and he was the highest-ranking technical expert at the company; he left Japan a former college professor of chemistry and returned as an Engineerin-Chief. He soon placed two orders: one for a coal mixing, washing, and grinding plant from Sheffield, and another for a battery of sixteen Semet-Solvay ovens from Brussels. This was an indication of a careful start, since a standardsize plant would have a battery of an average of 25 ovens. But it was SemetSolvay's first step into the potentially lucrative Japanese market. If successful, the Osaka installation would serve as a model plant, and Shimomura was given a monopoly over the sale of Semet-Solvay coke ovens in Japan in the hope that the business could expand, particularly to the Mitsui and Mitsubishi mining enterprises on the archipelago.

\section{Geology vs technology: high volatile content coal and innovations in coking protocol}

The Meiji period in Japan was a time of belief not only in the ideology of progress but also in the universal applicability (and thus transferability) of technology. In the realm of industrial development, progress in late nineteenthcentury Japan seemed to hinge on importing foreign technology for making a "rich country, strong army" (fukoku kyôhei) ${ }^{69}$ Like numerous examples of the impossibility of a simple, mechanical transfer of Western technology to Japan, byproduct coking was one of those areas that strongly challenged the universalist view of technology reigning among Meiji bureaucrats. This meant that purchasing ovens in Belgium and installing them in Japan was not a simple question of raising the capital and training or recruiting technical experts. Before the ovens could be successfully made to work and the enterprise could become profitable, Shimomura had to overcome a major obstacle inherent in seeking to combine Japanese coal and Belgian technology. Putting the plant into operation was not simply a question of unpacking and assembling the equipment according to the blueprints enclosed in the crates and written instructions from Brussels. This was mostly due to the fact that the imported

68. See references in the correspondence with the Hardy Patent Pick Co., Dôshisha University Archives, Shimomura Papers, G: Y-SK-6, folder 51.

69. Wittner 2008: 1-18. 
ovens were made to coke a kind of coal very different from the one Shimomura wanted to coke. Most European coking coals contained an average of $15 \%$ to $18 \%$ of volatile matter, and no Semet-Solvay coke oven in Europe had to coke coal above $22 \% .^{70}$ Practically all coal in Japan contained between $38 \%$ and $40 \%$ volatile matter. Given that the higher the volatile content in coal, the lower the quality of the coke produced from it, this was no small challenge. What may have initially seemed to Toyama a simple question of purchasing the equipment and shipping it to Japan turned out to involve considerable innovation in production protocols and raw material manipulation. This was in addition to trying to lower operating costs, secure a stable supply of raw materials, and reverse-engineering and improving pieces of equipment to keep the production going.

It took Shimomura about two years to start getting hard coke from a mix of local bituminous coal (40\% to $60 \%$ carbon content) and imported anthracite coal ( $90 \%$ carbon content). But he could not consider this a success because the process still depended on imported coal, albeit less of it. It took several more years of experimentation before he was able to develop a protocol for obtaining hard coke exclusively from local coal. ${ }^{71}$ By 1904, Shimomura had devised a procedure that dispensed with the use of imported anthracite coal and enabled coking of domestic high volatile - content coke without imported highquality coal. Perhaps the most interesting aspect of Shimomura's innovation was that it had more to do with the preparatory phase than with the actual coking in the ovens. There are two elements that were crucial to the success of the procedure: 1) Shimomura's decision, in preparing coal for coking, to grind before washing, and 2) the decision to coke specific coal mixtures in two steps instead of one, as was the norm of the day.

Of the two innovations, the former, namely grinding before washing, was the more controversial at the time. Early in the process of setting up the coking plant at the Osaka Chemical Works, Shimomura insisted on reversing the usual order of preparing coal for coking. He was warned by the Sheffield engineers from whom he bought coal-washing equipment that it was inadvisable and even "suicidal to grind this material before washing." If he "wish [ed] to be successful," they warned, he "must wash first and grind afterwards." They even

70. Four à Coke Semet-Solvay (1913): 63, Archives of the Solvay Corporate Secretariat, Brussels.

71. Letter from Shimomura Kôtarô, Osaka, to William Kirkpatrick, Brussels, September 16, 1899; Dôshisha University Archives, Shimomura Papers, G: Y-SK-6, folder 51. 
threatened not to send the equipment if he planned to use it in such a way. ${ }^{72}$ There was good reason for their misgivings about Shimomura's idea. The mixture of different sizes of coal allows a freer passage of water and prevents production of coal too fine to coke, not to mention requiring less time, labor, and water for the washing. ${ }^{73}$ While Shimomura knew all the arguments in favor of washing before grinding, he also knew that the kind of coal he wished to coke could benefit from any method of impurity elimination, no matter how outlandish it sounded in Sheffield. Grinding coal and thus physically breaking down its structure was a way to disrupt the impurities as well and literally try to wash some of them away before coking. In terms of labor hours and water use (and waste water created in the process), this was not the optimal way of preparing the coal for coking. But in terms of the geological equation Shimomura had to solve, it was perhaps one of the best solutions given his constraints (the poor quality of the coal) on the one hand and available resources on the other (the availability of water and relatively low costs of unskilled labor).

The second innovation, known and later patented as the Shimomura Procedure, was a protocol for mixing coal with semi-coke or X-coal, as Shimomura called it, instead of the commonly used anthracite. The principle of the process consisted in coking high volatile coals at $400^{\circ}$ to $600^{\circ} \mathrm{C}$, thus obtaining X-Coal, mixing it with high volatile coal in a proportion ranging from $15 \%$ to $40 \%$, and then proceeding to coke that in the usual way. ${ }^{74}$ The advantage of using semi-coke was that it could be produced by coking highly bituminous Japanese coal and could substitute for the imported anthracite coal. Although Shimomura's procedure made getting the final product a longer, two-step operation, its importance lay in that it was a technology that was operational solely using natural resources available on the archipelago itself, if necessary. This was of particular symbolic importance in the late 1890 s and early 1900 s due to the strong impulse to self-sufficiency driving the second wave of Japan's industrialization. ${ }^{75}$ Therefore, technologies such

72. Letters from Hardy Patent Pick Co., Sheffield, to Shimomura Kôtarô, Osaka, September 1, 1898, and September 6, 1898; Dôshisha University Archives, Shimomura Papers, RG: Y-SK-6, folder 53.

73. Letter from Hardy Patent Pick Co., Sheffield, to Shimomura Kôtarô, Osaka, July 6, 1897; Dôshisha University Archives, Shimomura Papers, folder 53.

74. Shimomura, Kôtarô. Shimomurashi sekitan teionkanryûhô-yûryô gaitan wo seizô (Shimomura Process of Low Temperature Carbonisation-Method of Producing Superior Coke). Dôshisha University Archives, Shimomura Papers, pamphlet, uncatalogued material, box 7 of 21 .

75. The rough periodization of Japanese industrialization in four phases-1868-1912 (beginnings), 1912-1945 (rapid growth, further stimulated by the war effort between 
as Shimomura's were as much appreciated as they were rare; they were both homegrown and reliant on locally available raw materials. ${ }^{76}$ At a political moment when the supply of raw materials (coal and iron ore) was far from secure and stable, this technology held a promise of energy self-sufficiency, albeit an economically and environmentally costly one.

\section{The making of an industry}

Similar to Ernest Solvay's interest in innovation in coking technology, a large part of Toyama's incentive for setting up his Osaka plant lay in the commercialization of the byproducts. The production of coke was a longterm goal, and devising a way of reaching it was made possible by the profits from the sale of byproducts. Thus Shimomura's principal job was increasing recuperation rates to enable the financial viability of the enterprise and allow him to pursue his interest in coke. It was his goal to produce metallurgical-grade coke without having to use imported coal that would become the trademark of his early career at Osaka Gas (1897-1905). In 1905, the combination of these two lines of work-byproducts and coke-brought him to the attention of General Nakamura Yûjiro (1852-1928), the head of the deeply-troubled government-run iron and steel venture, the Yawata Steel Works (Yawata seitetsujô). ${ }^{77}$

1937 and 1945), 1945-1970s (economic recovery), and 1980 to the present (period of de-industrialization) - is widely assumed to be axiomatic. See, for example, Gerteis 2013. There is still no consensus on the sub-periodization of Meiji industrialization (1868-1912). My use of the term "second wave" is an adaptation of Mosk's "second long wave." It refers to the period in which a capital-intensive massive industrial upswing, especially in the heavy-manufacturing sector, took place, becoming subsequently the driver of the Japan's economic growth in the 1910s.

76. This is evident not only from the fact that it was patented in Japan, but also by the fact of its longevity. It features prominently in US occupation - period reports on Japanese industrial capacity written half a century later. Unfortunately, data on sales of the patent are unavailable for this period. For an example of treatment of the Shimomura Procedure in the US occupation - period reports, see General Headquarters Supreme Commander for the Allied Powers, Natural Resources Section, Low Temperature Carbonization of Coal in Japan, Report no. 74, April 16, 1947; Dôshisha University Archive, uncatalogued material, box 3 of 21.

77. Yawata is the placename for the plant's location; seitetsujô literally means "ironmanufacturing place." The company name was commonly translated to English as either Yawata Steel or Yawata Steel Works and more rarely Yawata Iron and Steel Works. The rendering of the character tetsu as steel in this case is not a vestige of poor 
While small-scale efforts to modernize iron and steel production in Japan can be documented beginning in the final decades of the Tokugawa period (1600-1868), it was only after the Sino-Japanese war (1894-95) that the sense of urgency and influx of capital from war indemnities enabled the launch of a sustained effort in that direction. By the provisions of the Treaty of Shimonoseki (known in China as the Treaty of Maguan), the Qing Empire was to pay to Japan a sum of 200 million taels of silver (some 7,400 tons) as war indemnities. This sizable capital (amounting to 2.3 times the annual expenditures of Japan) enabled the allocation of 4 million yen for the building of a government-owned iron and steel plant. ${ }^{78}$ The estimate was based on an earlier proposal by Noro Kageyoshi (1854-1923), a metallurgy professor at the Imperial University of Tokyo, with a goal of the annual production of some 60,000 tons of steel. Between the approval by the Diet in 1895 and that establishment of Yawata as a legal entity a year later, however, Noro was implicated in a scandal that resulted in his being stripped of all public functions, including the advisory one in Yawata project. ${ }^{79}$

The implications for the plant proved significant. Noro's initial plan included a mix-and-match of equipment from different suppliers, including two Bessemer converters, four Siemens Martin open furnaces, six puddlers and one crucible furnace. His successor, Ôshima Michitarô (1860-1921), changed both the scale and the specifications of the equipment. With the backing of his father's reputation as Japan's pioneering metallurgist and his own credentials as a German-educated metallurgist, Ôshima was given a free hand in choosing Yawata's technological partner. His choice fell on a single company-Gutehoffnungshütte A.G. (GHH) - that was to provide a readymade solution for Japan's first iron and steel mill. While Noro's specifications were home-grown and involved starting a small plant before expanding it, Ôshima's idea was to leave the design and installation largely in the hands of the GHH engineers, doubling the size of the original plant, and hiring a team of German engineers and foremen to lead the installation. For a number of reasons, the cooperation between Japanese and German engineers and workers was less than amicable. Just to what extent things went sour is clear from the

understanding of the ferrous metals typology. Rather, the character tetsu is used to signify ferrous metals as a family of materials. Thus, in the metallurgical terminology of the time it was used in compounds such as kôtetsu (steel), chûtetsu (cast iron), or rentetsu (wrought iron).

78. Yonekura 1994: 37.

79. Noro's biography is based on Sôritsu nanjûsyûnen kinenn nippon tekko kyokai 1982: 169-177. 
fact that the majority of the Germans, including the Chief Engineer, Gustav Toppe, were dismissed before the end of their contracts, and one of the dozen Germans disappeared under what seemed to be mysterious circumstances. ${ }^{80}$ By the time of the first blow-in, in February 1901, only three German workers remained onsite.

Since the operation was an integrated iron and steel - making plant, its steel production was done in two steps. First the oxygen was removed from the iron ore in a blast furnace (iron ore reduction) turning it into molten pig iron. Poured out of the blast furnace, pig iron was then oxidized to remove a large portion of the carbon, thus making it into steel. In November 1901, the Imperial Yawata Steel Works were inaugurated in a solemn ceremony. But despite the initial enthusiasm, igniting the furnace was far easier than keeping it in continuous operation. Despite its high-end design, the furnace was considered to have performed poorly because the pig iron coming out of it was not suitable for steel production. While the quality of iron ore had something to do with the poor results, Noro concluded that one of the major problems was the poor quality of the coke used in smelting. ${ }^{81}$ One of most damaging technological consequences of the use of substandard fuel was that it was unlikely to produce temperatures high enough to yield a molten pig-iron mass. As a consequence, instead of flowing out of the oven in a molten state, heated iron lumps would harden on the walls of the blast furnace. This meant a complete interruption of the production, cooling down of the oven, and replacement of the blocked pipes and lower parts of the oven - a long and costly process.

Newly-found documentary evidence dating from 1898 shows that long before the coke became a major cause of a halt in production in 1902, Yawata engineers were well aware of the gravity of the problem. ${ }^{82}$ Yet they were unable to bring their point across so that the allocations would be made to build a top-of-the-line coking plant to go along the high-end blast furnaces. Instead, until 1905, Yawata kept focusing on improving the design of the blast furnaces and neglecting the coking facilities, entering a vicious circle of bad

80. For a seminal study of German influence on early Yawata technology and a Japanese translation of German documents pertaining to this period, see Fukuokakenshi 1995 and 1998. For a summary see Mathias \& Pauer 2004: 730-746.

81. Noro 1915: vol. 1, no. 8, 845-857 and vol. 1, no. 10, 1125-1138.

82. The private archive of Shimomura Kôtarô, discovered during my dissertation research in 2009, contains references to the 1898-1899 negotiations between Yawata Steel Works and Osaka Gas regarding the setting-up of a coking plant. These negotiations have previously gone unmentioned in any company history or analysis of the coke problem at Yawata. 
coke causing damage to the furnaces and more money going to their repair instead of addressing the root cause of the damage.

After production came to a standstill in April, 1902, General Nakamura was appointed Yawata's new director, and the beginning of his tenure was marked by a series of drastic measures that included the suspension of all attempts to blow-in the blast furnace, dismissal of the majority of employees, including top management personnel Chief Engineer Ôshima and W. Neuhauser, one of the two German foremen at the blast furnace, two years before the end of his contract. This meant that Noro's student Hattori Susumu (1865-1940) and seven German foremen were left to restart the production and build a second blast furnace. Shortly after, with the scandal that had cost him his position several years earlier largely forgotten, Noro Kageyoshi was brought to Yawata to help with the revival efforts. Although he clearly identified the lack of goodquality coke as a major technical reason for Yawata's crisis, his experience in that field was limited. While he was able to improve the design of the first blast furnace and help Hattori to build the second blast furnace with minimal help from two German foremen, he was unable to offer a practical solution to the coke problem.

By March 1904, Japan was at war with Russia, a major military engagement, and the second blast furnace at Yawata was ready for blow-in, but the existing in-house coking facilities were still performing poorly. Aware that without good coke, the second blast furnace would share the fate of the first, Nakamura embarked on an inspection of coking facilities in the country. In early 1904, during a visit to the Osaka Chemical Works, he met Shimomura, a man who seemed capable of helping Yawata. Nakamura had good reasons to be interested in Shimomura as much as to be suspicious of him. On the one hand, by this time Shimomura had the experience-unique in Japan - of setting up and running a byproduct coking plant. Not only could he set up a production protocol for obtaining blast-furnace grade coke, but he could also help Yawata collect and commercialize coal tar, one of the byproducts of coking and an indispensable ingredient for much-needed coal briquettes used as naval fuel. ${ }^{83}$

However, Shimomura must have struck Nakamura as an odd, if not suspicious, figure for at least two reasons. First, he was very different from other engineers Nakamura interacted with at Yawata or those he would later meet in Manchuria. During Nakamura's time at Yawata, virtually all the engineers for whom data is available were graduates of the University of Tokyo's Science Department, the Kôbudaigakkô (the College of Engineering and Technology), today's Faculty of Engineering, which was founded in 1877. Those who, like

83. Evans and Peattie 1997: 66. 
Noro, graduated in the 1880s had studied under the Kôbudaigakkô's foreign experts, who had been hired to teach and train future Japanese faculty, and they often logged years of study abroad. Noro himself spent seven years studying mechanical and electrical engineering at the University of London and metallurgy at Freiberg University of Mining and Technology in Germany. The following generation, represented at Yawata by Hattori Susumu, the head of the blast furnace division at the time of the coke crisis, was less likely to have been abroad and more likely to come to Yawata straight from their Tokyo classrooms. Shimomura was not a graduate of the University of Tokyo nor was he connected to it in any way. Seven years younger than Noro, Shimomura had a profile and career with little in common with Noro's or with that of most Yawata engineers; he was in many ways an outsider.

Second, Shimomura was very likely the only practicing Protestant Christian with whom Nakamura dealt professionally, since Christians were virtually absent from high Army echelons. At the time the two met, Shimomura was the president of his alma mater, Dôshisha, a church member, and the leading pastor of the college's congregation. In the late-Meiji mindset, Christians could hardly be patriots since their loyalties were suspect. According to the stereotypical view, they bowed to Jesus instead of the emperor and had perhaps too close ties with foreigners. In today's vocabulary, one might say that, from Nakamura's perspective, Shimomura was not the ideal candidate for a security clearance and full access to one of the country's major military facilities. Yet it was precisely Shimomura's identity and itinerary as an outsider to the nation's science and technology mainstream that facilitated his acquisition of the technological know-how that would turn out to be game-changing for the Imperial Steel Works and propel Nakamura's career. This acknowledgement that he gained as the man who brought Yawata from ruin to profitability would contribute to his future political career. In 1914, when Yawata was profitable, Nakamura was appointed Director of the South Manchurian Railroad (a conglomerate that coordinated Japanese penetration into Manchuria) which was a major promotion and a stepping-stone into big-league politics.

Shimomura's expertise outweighed Nakamura's possible suspicions, and in 1905 Shimomura helped put in an order for 75 coke ovens for Yawata. In 1906 he made several trips to Kyûshû to install the ovens and train the engineers and foremen in operating them. The first half of the total of 150 ovens was installed in November 1906, while the rest were put in operation between 1907 and 1909. As noted above, the key element in coking local coal and getting metallurgical-grade coke lay not in learning how to use the ovens themselves but in mastering the art of preparing and mixing the coal. One of Shimomura's brightest students was the young Kuroda Taizô (1883-1961). Born in Osaka, 
twenty-two years old and only half of Shimomura's age at the time, he was a recent graduate of the Imperial University of Tokyo's School of Engineering. Hired a few months before Shimomura was brought to consult at Yawata, he was seemingly a fast learner and soon became Yawata's foremost coke expert. ${ }^{84}$

With Shimomura's procedure in place and the Semet-Solvay ovens operating, Yawata had finally obtained the coke it needed to start efficient operation. A year after the planned coking plant was installed in 1909, Yawata registered its first profits, and Shimomura, uninterested in moving to Yawata, could return to his research in byproduct chemistry. On the evening of August 14,1914 , however, there was an explosion in his private laboratory in Kyoto, and Shimomura suffered burns to his hands and face, severely damaging his eyesight. The explosion took place just as Japan was heading into a conflict against Germany. Only a few hours before Shimomura went into his laboratory on that evening, Japan had issued an ultimatum to Germany to remove all its soldiers and armed vessels from Japanese waters and to deliver to Japanese authorities the Kiaochau concession (Jiaozhou Bay), a recently acquired $552 \mathrm{~km}^{2}$ German foothold in northern China. Most agreed that this ultimatum would lead to Japan's entry into what was becoming a major global conflict.

For a Japanese chemist like Shimomura, impending war with Germany had one significant implication: imports of dyestuffs were going to be interrupted at the time when $90 \%$ of synthetic dyes used in textile and related industries were imported from Germany. As a chemist, Shimomura was well aware that war with Germany would thus mean an interrupted supply of synthetic dyes from Germany and "a dyestuff famine." ${ }^{85}$ Synthetic dyestuff were an essential component of Japan's textile industry, the country's premier export. Thus, the Japanese ultimatum would mean an economic crisis by practically halting textile exports. Shimomura went into his private laboratory that Sunday to try to reproduce an experiment he noted during his time at Johns Hopkins, fifteen years before, and which he hoped could help to synthesize a black dye. ${ }^{86}$ It was during this attempt that an explosion took place. Although his eyesight partially recovered and he was able to continue his career as the Managing Director of the Osaka Chemical Works, the accident forced his research career into quieter waters. He continued being an important player in the chemical industry while occupying positions at the Japanese Dyestuff Company and the Japanese Wood-preservation Company. He also went on to publish a

84. Kuroda 1912.

85. Hashimoto 2007: 36.

86. Shimomura, Kôgyô rireki. 
collection of poems, a book of philosophical reflections on the human soul, and an autobiography.

\section{Conclusion}

From the outline of his personal and professional itinerary, it is clear that as a chemical engineer Shimomura was both exceptional and marginal. At the same time, Shimomura's life, travels, and work are of interest precisely because they can help add nuance to our understanding of the emergence of the engineering profession, the public-private cooperation in late-Meiji heavy industry, and the place of technological innovation in the study of Japanese industrialization. ${ }^{87}$

In existing studies on the emergence of the specific category of an engineer, careful attention has been given to the difficulty of studying the subject due to a confusion in terminology used. In particular, the term "engineer" or gishi rarely appears in company records until 1905 . When it does, it can figure as a category in civil-service ranking and not necessarily designate a person with technical qualifications. Thus, analyses hinge on the close examination of a number of generic terms, such as shokutaku, joshu, yatoi, or gitei, used to designate a person whose job description requires some level of technical training. Regardless of the terms used, current consensus is that most technicians were trained on the job or in technical schools organized in connection with large industrial complexes. ${ }^{88}$ A minority of technically-trained men and a majority of those we could comfortably call engineers had diplomas from the Imperial Universities. I would like to suggest that Shimomura's career and itinerary reveals a need to broaden this typology and that there may have been different kinds of engineers, notably those trained at a high level but outside the Imperial University network, who worked toward Meiji industrial development. This opens the question of whether, although less visible in the archives, engineers educated at small private colleges and/or trained abroad may have been just as creative and productive as their counterparts trained in Tokyo, and later Kyoto.

This leads to the second important question that Shimomura's career raises. Up until the 1990s, small and medium-size companies were considered as a residue or vestiges of the feudaleconomy. With the pioneering work of economists such as Sawai Minoru and Suzuki Jun, small and middle-size enterprises

87. See, among others, Pauer 2013, Sawai 2012, Sawai 1998, Odaka and Sawai 1999, and Suzuki 1996.

88. For example, see Uchida 1974; Fukasaku 1992: 57-78; and Sawai 2012. 
emerged as active and important elements of Japanese industrialization, the spiritus movens of a dynamic private sector. ${ }^{89}$ Regardless of its aspirations and later development, during the late Meiji period, Osaka Chemical Works was one of those medium-size companies. What Shimomura's itinerary reveals is that not only were small and medium-size companies important ingredients of economic growth but that they were also important sites of technological innovation. This is not a point of minor importance. In theory, knowledge of the latest development in byproduct coking existed at both Osaka Chemical Works and at Yawata. In practice, it was the much smaller Osaka Chemical Works that invested in bringing the technology to Japan and building expertise. This required adapting the technology to the local raw materials-a complex, expensive and lengthy project. Once Shimomura developed a coking protocol that enabled the use of Semet-Solvay ovens with local Kyûshû coal in a medium-size, private venture, the state-run Yawata Steel Works absorbed the technology, albeit with next to no acknowledgement of either Shimomura's role or that of the Osaka Chemical Works. I would like to suggest that this episode opens the question of the role of small and medium-size companies in technological innovation, as distinct from the overall economic growth, that characterized Meiji industrialization.

Finally, Shimomura's innovations are an excellent example of the changes that technical knowledge undergoes in the process of circulation. His career shows that the notion of technology transfer conceived of merely as a mechanical transplantation from place A to place B is simplistic. The circulation of technological expertise does not simply rely on reproduction but depends in great measure on innovation. Shimomura's effort to bring byproduct coking technology from Belgium to Japan depended as much on him learning its rules in Brussels as it did on his figuring out a way to adapt those same rules in order to accommodate a local configuration of resources. In that, the attempt to coke Japanese coal in the Semet-Solvay ovens, unsucessful at first because the ovens were designed to coke a different kind of coal, is not very different, for example, from the failure of a French-made Gasogen device to function in Costa Rica because it was fed a different kind of wood. ${ }^{90}$ This story suggests that in Meiji Japan, too, complex technological systems could not be simply plugged in but had to be redesigned before they could even begin to be reasonably workable. This in turn suggests that, upon closer inspection, the importation of technology in Japan, as elsewhere, has been coupled with more innovation than Meiji oligarchs and bureaucratcs would lead us to believe.

89. See Sawai 1998, Odaka and Sawai 1999, and Suzuki 1996.

90. Akrich 1994: 289-337. 


\section{Bibliography}

\section{Archives}

Archives of the Solvay Corporate Secretariat, Brussels, Belgium.

Ferdinand Hamburger Archives of The Johns Hopkins University, Baltimore (Md.), USA.

Dôshisha University Archives, Shimomura Papers, Kyoto, Japan.

Kumamoto Prefectural Library, Archive section, Kumamoto, Japan.

Worcester Polytechnic Institute Archive, Worcester (Mass.), USA.

Yale Divinity School Archives, New Haven (Conn.), USA.

\section{Published sources}

ABE Isoo 阿部磯雄 (2009). Abe Isoo Nikki: Seishunhen 阿部磯雄日記: 青春年 (Diary of Abe Isoo: Youth). Kyoto, Dôshisha University Archives.

AKrich Madeleine (1994). "Essay of Techno-Sociology: A Gasogen in Costa Rica." In Pierre Lemonnier (ed.), Technological Choices. London, Routledge: 289-337.

Andersen Gerald H. (1999). Biographical Directory of Christian Missions. Grand Rapids (Michigan), Wm. B. Eerdmans Publishing Co.

Ballhatchet Helen (1988). "Confucianism and Christianity in Meiji Japan: The Case of Kozaki Hiromichi." Journal of the Royal Asiatic Society of Great Britain and Ireland, no. 2: 349-369.

Bartholomew James (1989). Foundation of Science in Japan: Building a Research Tradition. New Haven and London, Yale University Press.

Bertrams Kenneth, Coupain Nicolas and Homburg Ernst (eds.) (2013). Solvay: History of a Multinational Family Firm. New York, Cambridge University Press.

Bouquet Olivier (2007). Les Pachas du Sultan: essai sur les agents supérieurs de l'État Ottoman (1839-1909). Collection Turcica, Leuven, Peeters.

Bretelle-Establet Florence (2009). "Chinese Biographies of Experts in Medicine: What Uses Can We Make of Them?" East Asian Science, Technology and Society: An International Journal, vol. 3, no. 4: 421-451.

Burn Duncan L. (1961). The Economic History of Steelmaking, 1867-1939: A Study in Competition. New York, Cambridge University Press.

Cohen Doron B. (2013). The Japanese Translation of the Hebrew Bible. Leiden, Brill. Dôshisha circular 1885. Yale Divinity School Archives.

Dôshisha Faculty Records 1879-1895 (2004). Kyoto: Dôshisha Archives.

Dôshisha hyakunenshi (1979) 同志社百年史 (Centennial history of Dôshisha). Kyoto: Dôshisha University.

EBINA Danjô 海老名弾正 (1935). Kumamoto yôgakko to Kumamoto Bando 熊本洋学 校と熊本バンド (Kumamoto School for Western Learning and the Kumamoto Band). Pamphlet of a lecture delivered in Kumamoto at the Kaikosha, June 23. 
Evans David and Peattie Mark (1997). Kaigun: Strategy, Tactics, and Technology in the Imperial Japanese Navy 1887-1941. Annapolis (Md.), Naval Institute Press.

Feng Di and Shao Dongfang (1994). "Life-writing in Mainland China (1949-1993): A General Survey and Bibliographic Essay." Biography, vol. 17, no. 1 (Winter): 32-55.

Four à Coke Semet-Solvay (1913). Bruxelles. Archives of the Solvay Corporate Secretariat, Brussels, Belgium.

FuKASAKu Yukiko (1992). Technology and Industrial Development in Pre-War Japan: The Mitsubishi Nagasaki Shipyard 1884-1934. London, Routledge.

Fukuokakenshi shiryôhen: Yawataseitetsujô 福岡県史: 八幡製鉄所 (1995), vol. 1. Fukuoka, Nishinihon bunka kyôkai.

Fukuokakenshi shiryôhen: Yawataseitetsujo 福岡県史: 八幡製鉄所 (1998), vol. 2. Fukuoka, Nishinihon bunka kyôkai

FuKUnAGA Bunnosuke 福永文之助 (1893). Nihon ni okeru tahô jensushi 日本におけ る大尉 ジェン史 (Captain Janes and his Work in Japan). Tokyo, Keiseisha.

Fulton John (1895). Coke: A Treatise on the Manufacture of Coke and the Saving of By-Products. Scranton (Pa.), The Colliery Engineer Co.

GERTEIS Christopher (ed.) (2013). Critical Readings on the History of Industrialization in Modern Japan. Leiden, Brill.

Gyatso Janet (1998). Apparitions of the Self: The Secret Autobiographies of a Tibetan Visionary. Princeton, Princeton University Press

Haber L. F. (1971). The Chemical Industry, 1900-1930: International Growth and Technological Change. Oxford, Clarendon Press.

Harootunian Harry D. (1970). Towards Restoration: The Growth of Political Consciousness in Tokugawa Japan. Berkley, University of California Press.

Hashino Tomoko (2007). "The Rise of the Japanese Synthetic Dyestuff Industry During the First World War." Kobe University Economics Review, no. 53: 35-55.

Hearn Lafcadio (1922). The Writings of Lafcadio Hearn. 16 vols. Boston: Houghton Mifflin.

Higo han kokuji shiryô 肥後藩国事史料 (Higo domain official affairs documents) (1932), vol. 10. Kumamoto: Kôshaku hosokawakei hensanjo.

Horiuchi Annick (2010). Japanese Mathematics in the Edo Period (1600-1868): A Study of the Works of Seki Takakazu (?-1708) and Takebe Katahiro (1664-1739). Basel, Birkhäuser.

JANes Capt. L. L. (1970). Kumamoto: An Episode in Japan's Break from Feudalism. Kyoto, Dôshisha University Archives.

Kiristosha retsuden: shinkô sanjûnen (Christian Lives: Thirty Years of Faith) (1921). Tokyo, Keiseisha shoten.

KoBILJSKI Aleksandra (2014). “'Croyez-vous à la prière?'-La vie spirtuelle d'un scientifique japonais tombé dans l'oubli." Revue d'Histoire Moderne et Contemporaine (forthcoming).

KozAKI Hiromichi (1933). Reminiscences of Seventy Years: The Autobiography of a Japanese Pastor. Tokyo, Kyôbunkan. 
KuRODA Taizô 黒田泰造 (1912). Saikin gaitan seizôhô oyobi fukusannbutsu shorihô 最近骸炭及び副産物処理法 (Latest Method for Coke Production with the Methods of By-product Treatment). Tokyo, Maruzen.

Mathias Regine and Pauer Erich (2004). "Entwicklungshilfe für Japan: Der Beginn der moderne japanischen Eisen- und Stahlindustrie mit Technologie aus dem Ruhrgbeit.” In Rasch, Manfred and Bleidick, Dietmar (eds.). Bleidick Technikgeschichte im Ruhrgebiet: Technikgeschichte für das Ruhrgebiet. Essen, Klartext Verlag: 730-746.

Mryauchi D. Y. (1968). "Kokuze Sanron: The Three Major Problems of State Policy, recorded in the 1st year of Man'en (1860) at Fukui, Echizen Province, by Yokoi Shônan. An annotated translation.” Monumenta Nipponica, vol. 23, no. 1/2: 156186.

Mizuno Hiromi (2008). Science for the Empire: Scientific Nationalism in Modern Japan. Stanford, Stanford University Press.

Mosk Carl (2001). Japanese Industrial History: Technology Urbanization and Economic Growth. Armonk, N.Y., M. E. Sharpe.

NAKAOKA Tetsurô 中岡哲郎 (2006). Nihon kindai gijutsu no keisei: “dentô" to "kindai” no dainamikusu 日本近代技術の形成: “伝統”と“近代”のダイナミクス (The Formation of Modern Japanese Technology: The Dynamics of "Tradition" and "Modernity"). Tokyo, Asahi Shinbunsha.

Niijima Jô ate eibun shokan 新島裏宛英文書物 (English Letters Addressed to Niijima Jô) (2007). Kyoto, Dôshisha Center for Humanities and Dôshisha University.

Noro Kageyoshi 野呂景義 (1915). “Honpô seitetsu jigyô no kako oyobi shorai” 本 邦製鉄事業野過去及び将来 (The Past and Future of Japan's Iron and Steel Industry). Tetsu to Hagane (Iron and Steel).

Notehelfer F. G. (1985). American Samurai: Captain L. L. Janes and Japan. Princeton, Princeton University Press.

OdaKa Konosuke and SawaI Minoru (eds.) (1999). Small Firms, Large Concerns: The Development of Small Business in Comparative Perspective. Oxford, Oxford University Press.

PAsseron Jean-Claude (1990). "Biographies, flux, itineraries, trajectories." Revue française de sociologie, vol. 31, no. 1: 3-22.

PAUER Erich (2013). "The Search for (Social) Identity: Japanese Engineers, 19101940." Icon, vol. 18: 86-103.

ReVel Jaques (1996). Jeux d'échelles: la micro-analyse à l'expérience. Paris, Gallimard. SAWAI Minoru 沢井実 (1998). Nippon tetsudô sharyô kôgyôshi 日本鉄道車輛工 業史 (The history of the Japanese railroad car industry). Tokyo, Nihon keizai hyoronsha.

SAWAi Minoru (1999). "Meiji chûkôki Osaka no kikai kôgyô (Machinery Industry in the Second Half of the Meiji Period). Osaka Daigaku Keizaigaku 大阪大学経済学 (The Economic Review of Osaka University), no. 48 (3/4): 111-141.

SAWAI Minoru (2012). Kindai Osaka no kôgyô kyôiku 近代大阪の工業教育 (Industrial Training in Modern Osaka). Osaka, Osaka Daigaku Shuppankai. 
SHIMAO Eikoh 島尾永康 (1975). “下村孝太郎先生 一八リ ス理科学校と化学工業 における創業” (Professor Kotaro Shimomura: The Establishment of the Harris School of Science and Chemical Industry). Dôshisha Jiho, vol. 53: 4-10.

SHIMAo Eikoh 島尾永康 (1991). "Shimomura Kôtarô-sono senkuteki gyôseki to jinbutsuzô” 下村孝太郎一その先駆的業績と人物像 (Shimomura Kotaro: His Pioneering Works and Personality). Kagaku kenkyû 化学史研究, vol. 18, no. 4 (Dec. 1991): 197-210.

SHIMAO Eikoh (2002). Jinbutsu kagakushi 人物化学史 (Portraits in the History of Chemistry). Tokyo, Asakura shoten.

SHImomura Kôtarô 下村孝太郎 (1931). Waga shûkyô kan 和が宗教観 (My View of Religion). Kyoto, Minyusha.

Shimomura Kôtarô ( ca 1887). The Aim of My Life, typescript. Dôshisha University Archives, call no. RG: Y-SK- 6.

SHIMOMURA Kôtarô (1925). Kôgyô rireki 工業履歴 (Summary of my career in industry). Dôshisha University Archives, Shimomura Papers, call no. RG: Y-SK-G, folder 13.

SHImomURa Kôtarô. Shimomurashi sekitann teion kanryûhô-yûryô gaitan wo seizô 下 村氏石炭低温乾留法 - 優良骸炭を製造する方法 (Shimomura Process of Low Temperature Carbonisation-Method of Producing Superior Coke). Dôshisha University Archives, Shimomura Papers, pamphlet, uncatalogued material, box 7 of 21.

Sôritsu nanjûshûnen kinenn nippon tekko kyokai 創立七十周年記念日本鉄鋼協会史 (70th Anniversary History of Japanese Iron And Steel Institute) (1982). Tokyo, Yuhaikaku.

Sôritsuki no Dôshisha: sotsugyôseitachi no kaisorokoku 創立期の同志社: 卒業生 達の回想録 (Early Dôshisha: Alumni Recollections) (1986). Kyoto, Dôshisha University Archives.

SUzUKI Jun 鈴木淳 (1996). Meiji no kikai kogyô: sono seisei to tenkai 明治の機械

工業：その生成と展開 (Machine Industry in the Meiji Period: Its Birth and Development). Kyoto, Minerva Shobô.

Travers Alice (2009). "Risk and Social Mobility: A Study of Demotion and Dismissal Cases in the Careers of dGa'Idan pho brang Officials from 1885-1952." In Dotson, Bradon, Gurung, Kalsang Norbu, Halikias, Gerigios and Myatt, Tim (eds.), Contemporary Visions in Tibetan Studies: Proceedings of the First International Seminar of Young Tibetologists. Chicago, Serindian Publications: 363-381.

UCHIDA Hoshimi 内田星美 (1974). Sangyo gijutsushi nyumon 産業技術史入門. Tokyo, Nihon keizai shibunsha.

WARNER Deborah J. (2008). "Ira Remsen, Saccharin, and the Linear Model." Ambix, vol. 55, no. 1, March 2008: 50-61.

WitTNER David (2008). Technology and the Culture of Progress in Meiji Japan. New York: Routledge.

YAMAZAKI Masatada 山崎正董 (1938). Yokoi Shônan. 2 vols. Tokyo, Meiji shoin.

YoneKuRA Seiichi (1994). The Japanese Iron and Steel Industry, 1850-1990. New York,

St. Martin's Press. 
Aleksandra Kobiljski

\section{Glossary}

Chôchû 長州

chûtetsu 鋳鉄

Dôshisha 同志社

difang zhi 地方志

Edo 江戸

fukoku kyôhei 富国強兵

Fukui 福井

Gakkotô 学校党

gishi 技師

gitei 技手

Hakkenden 八犬伝

Hattori Susumu 服部進

Higo 肥後

Hizen 肥前

Hosokawa 細川

Jishûkan 時習館

Jitsugaku 実学

Jitsugakutô 実学党

$j o s h u$ 助手

Kiaochau (Jiaozhou) 胶州

kirishitan bateren hon キリシタンバテレン本

kirishitan bateren キリシタンバテレン

kirisutan bateren キリスタンバテレン

Kôbudaigakkô 工部大学校

$k \hat{o} k i$ 好機

koku 石

Kokuze sanron 国是三論

kôtetsu 鋼鉄

Kumamoto bando 熊本バンド

Kumamoto yôgakko 熊本洋学校

Kumamoto 熊本

Kuroda Taizô 黒田泰造

Kyoto 京都

Kyûshû 九州

Maguan (Treaty of) 马関条約

Matsudaira Shungaku 松平春獄

Matsukata Masayoshi 松方正義

Meiji 明治 
Morita 森田

Nakamura Yûjiro 中村雄次郎

Niijima Jô 新島襄,

Noro Kageyoshi 野呂景義

Osaka 大阪

Ôshima Michitarô 大島道太郎

rentetsu 錬鉄

rônin 浪人

Sakuma Shôzan 佐久間象山

Satsuma 薩摩

Sawai Minoru 沢井実

Sensei 先生

Shimomura Kôtarô 下村孝太郎

Shimonoseki 下関

shokutaku 嘱託

sonno jô $i$ 尊皇攘夷

Suzuki Jun 鈴木淳

Takezaki Sadô 竹崎茶堂

Takizawa Bakin 滝沢馬琴

tetsu 鉄

Tokugawa 徳川

Tokutomi Ikkei 徳富一敬

Tokyo 東京

Tosa 土佐

Toyama Shûzô

Tôyô no dôtoku, seiyô no gakugei 東洋の道徳西洋の学芸

tozama 外樣

Wakon yôsai 和魂洋才

wasan 和算

yatoi 雇

Yawata seitetsujô 八幡製鉄所

yôgaku 洋学

Yokoi Shônan 横井小楠

yôsan 洋算 